\title{
What kind of women' education that affects economic growth?
}

\author{
Aïcha EL ALAOUI
}

University of Sultan My Slimane. Faculty Poly-disciplinary. BP: 591, Av. Ibn Khaldoun, CP: 23000, BeniMellal, Morocco. Tel. (+212) 6635052 11. Email: aicha_elalaoui@yahoo.fr

\begin{abstract}
This communication tries to examine what kind of women' education affects more economic growth. To illustrate this aim, four countries cases have been presented: Morocco, Algeria, Tunisia, and Egypt. The motive behind choosing them was because these countries have many common characteristics (religious and cultural norms and values). Using panel model over the period 2000-2012, the results show that women' education, particularly, tertiary education, women' labour force participation and institutional capital affect positively economic growth. On the contrary, the primary and secondary school enrolment are negatively linked to the economic growth. This paper concludes that women' tertiary education is a master-key to improve economic growth and development accompanied by a healthy and good quality of institutional capital and by eliminating all forms of gender discrimination.
\end{abstract}

Key words: Economic growth - Panel analysis - Women' education - Institutional capital 


\section{Introduction}

In the early 60s, economists have given a big importance to the concept of human capital principally with the writing of Becker (1962), Schultz (1961, 1962), Mincer (1958, 1962), Kiker (1966) and Blaug (1976). They are confirmed that human capital is an important component in economic growth and sustainable development. Human capital and economic growth have a positive and long-run relationship. It is an important factor to decrease poverty and migration, reduce fertility rate and infant mortality, and increase labour participation, total factor productivity, health, and life's conditions.

Human capital includes education, health, and "social capital", (Barro, 2013). It is referred "to the knowledge and capabilities embodied in people that can be utilized to advance the production techniques and contribute to the social and economic development", (Organization of Islamic Cooperation (OIC), 2011, p. 1). Thus, education plays a considerable role in the human capital accumulation.

Studying and measuring the impact of human capital on economic growth is always important, especially, in developing countries where the school enrolment remains feeble, mainly for girls and in rural area. The literacy rate of female is still lower than that of male in developing countries albeit that women' education has positive direct and indirect effect on the economic growth (Psacharapoulos (1994), Hill and King (1995), Barro (1996), Klasen (2002), and Bloom, Canning and Chan (2006)).

This communication tries to investigate effects of the education, as measures of human capital, on the economic growth in Morocco, Algeria, Tunisia, and Egypt, noted MATE. The human capital refers to both women and men. The proportion of women is a little over half of the World's population which is similar to that of the countries under study. However, the women' contribution in economic growth and wellbeing is far below their potential, which leads to serious microeconomic and macroeconomic consequences, especially, in developing countries including MATE. Using a panel model over the period 2000-2012, we try to investigate if women' education can contribute positively in economic growth like men' education and to determine the level of education (primary, secondary and/or higher education) that can contribute more in economic growth in these countries.

This communication will be presented as follows. Second section describes the economic situation and education development in MATE. Third section is dedicated to present the methodology used in this study and to discuss the main results and findings. Last section is served to conclude.

\section{Economic and Social Situation in MATE}

Despite their differences in their macroeconomic structure and political systems, MATE have a larger resemblance in society's characteristics. In its report, UN-Women (2013) declared that "the Arab countries have in common many cultural, historical and geographical aspects" where "more or less women have suffered - and continue - from legal, economic, sociocultural and political discrimination", (UN-Women, 2013, p. 7).

Social development in MATE differs significantly from a country to a country and within the same country as economic growth, education, health, institutional capital, and natural capital. Economic growth in Morocco is speedily growing and reached 3.9\% during 2010-2013 against 3.1\%, 2.8\% and 2.6\% in Algeria, Egypt and Tunisia, respectively. Figure 1 provides an idea of the average growth of real GDP over the period spanning from 1970 to 2013. 
Figure No1. Growth rate of the real GDP (constant 2005 US\$) in MATE, 1970-2013

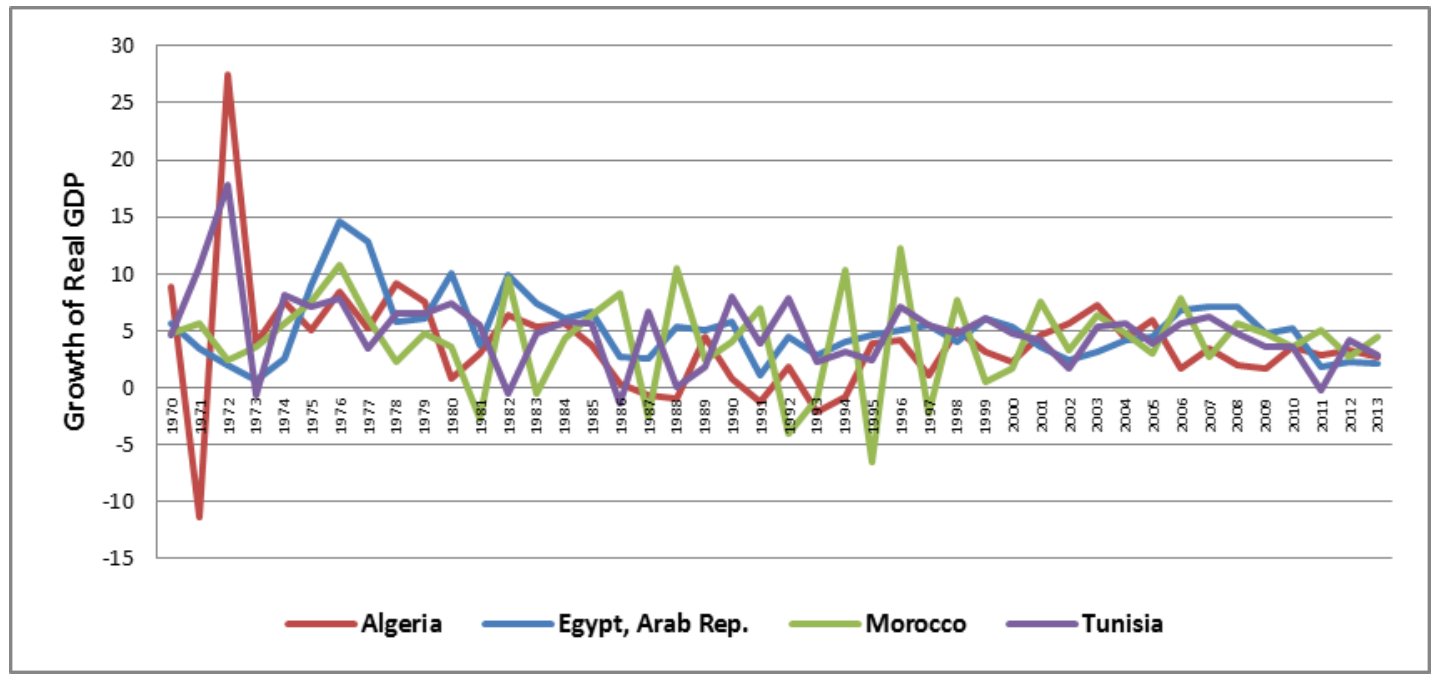

Source: Elaborated using data of World Development Indicators (WDI), 2015.

Figure 2 shows that the real GDP per capita (constant 2005 US\$) of the World is higher than that of MATE. There is a considerable divergence between them; the average real GDP per capita in MATE is only $\$ 1775.72$ and that in the World is $\$ 5484.83$. However, the real GDP per capita (constant 2005 US\$) of OECD members is very higher than that of MATE and the World.

Figure No2. Growth of the real GDP per capita (constant 2005 US\$) in MATE, OECD members and the World over the period 1960-2013

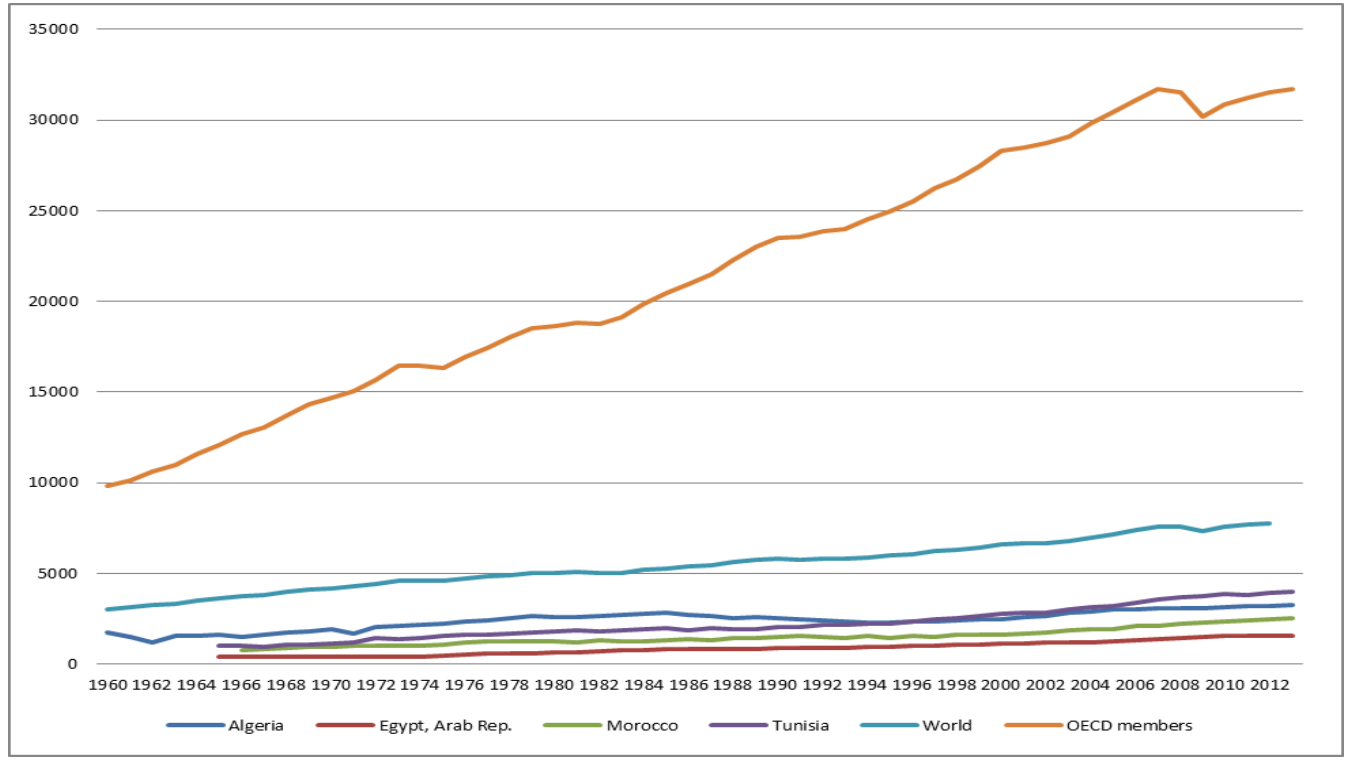

Source: Elaborated using WDI, 2015

Due to important political and social development realized by MATE albeit there are limited, the roles of women in these societies were enlarged. Improvement of women' contribution in the political activity, increasing their participation in the labour force, and reinforcement the role of the law and justice are the principal sources of these political and social developments. Consequently, the improvement in women' situations are changed many aspects of the society. Using data from WDI (2015) over the period 1960-2013, four economic and social aspects of change in MATE can be identified : (1) the fertility rate is on its downward trend; (2) the average literacy rate of female is lower than that of male; (3) the average labour force participation of female in MATE is lower than that of male, and that of other regions of the 
World; (4) mortality rates of neonatal, baby and infant in MATE are lower than those of the World. In following, we explain these changes and theirs effect on the economic growth.

$\Rightarrow$ First change on MATE is that the fertility rate is on its downward trend from 7 children to around 3 children, Figure 3. The same trend is recorded in the World, South Africa and South Asia where the fertility rate is at around 3 children. But, this rate remains higher in SSA at around 5 children.

Figure No3. Fertility rate in MATE and in other regions of the World, over the period 1960-2013

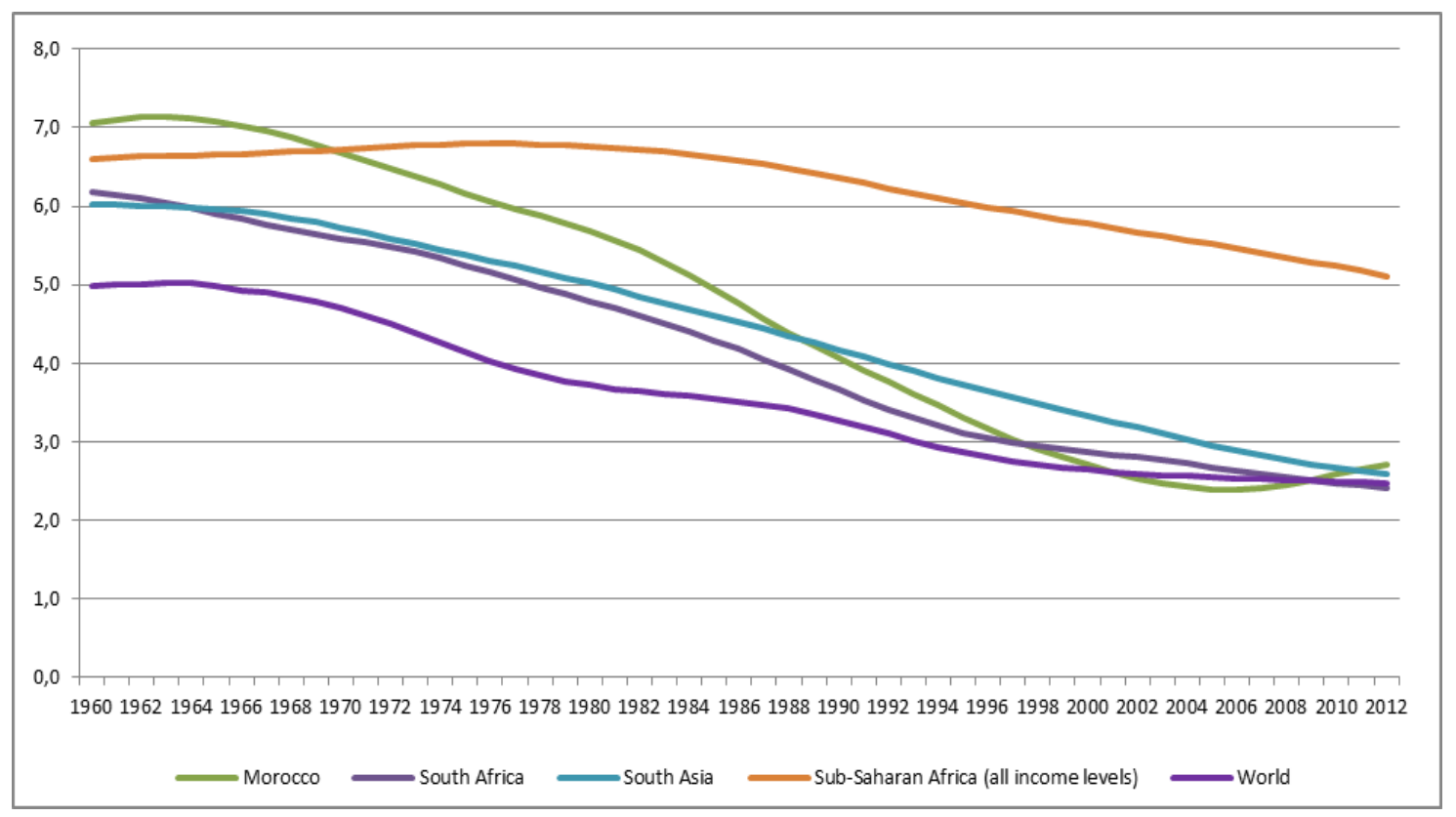

Source: Elaborated using WDI, 2015

Several factors could be having an effect on diminution of the fertility rate as amelioration in the economic growth, intensive participation of women in labour force ${ }^{1}$ and increase in the 'literacy rate'. This rate is measured, in this study, by four indicators: 'primary completion rate', 'primary school enrolment', 'secondary school enrolment', and 'tertiary school enrolment'.

Figure 4 draws a statistical relationship that links a simple regression of (1) fertility rate (noted TFR) and real GDP per capita (noted $\mathrm{g}_{\mathrm{y}}$ ); (2) fertility rate and women' participation in labour force (noted LF); and (3) fertility rate and primary completion rate of female (noted HCP-F).

\footnotetext{
${ }^{1}$ The female labour force is defined "as a percentage of the total shows the extent to which women are active in the labour force. Labour force comprises people ages 15 and older who meet the International Labour Organization's definition of the economically active population", World Bank, WDI, 2015.
} 
Figure No4. Statistical relationship of MATE over the period 1980-2012

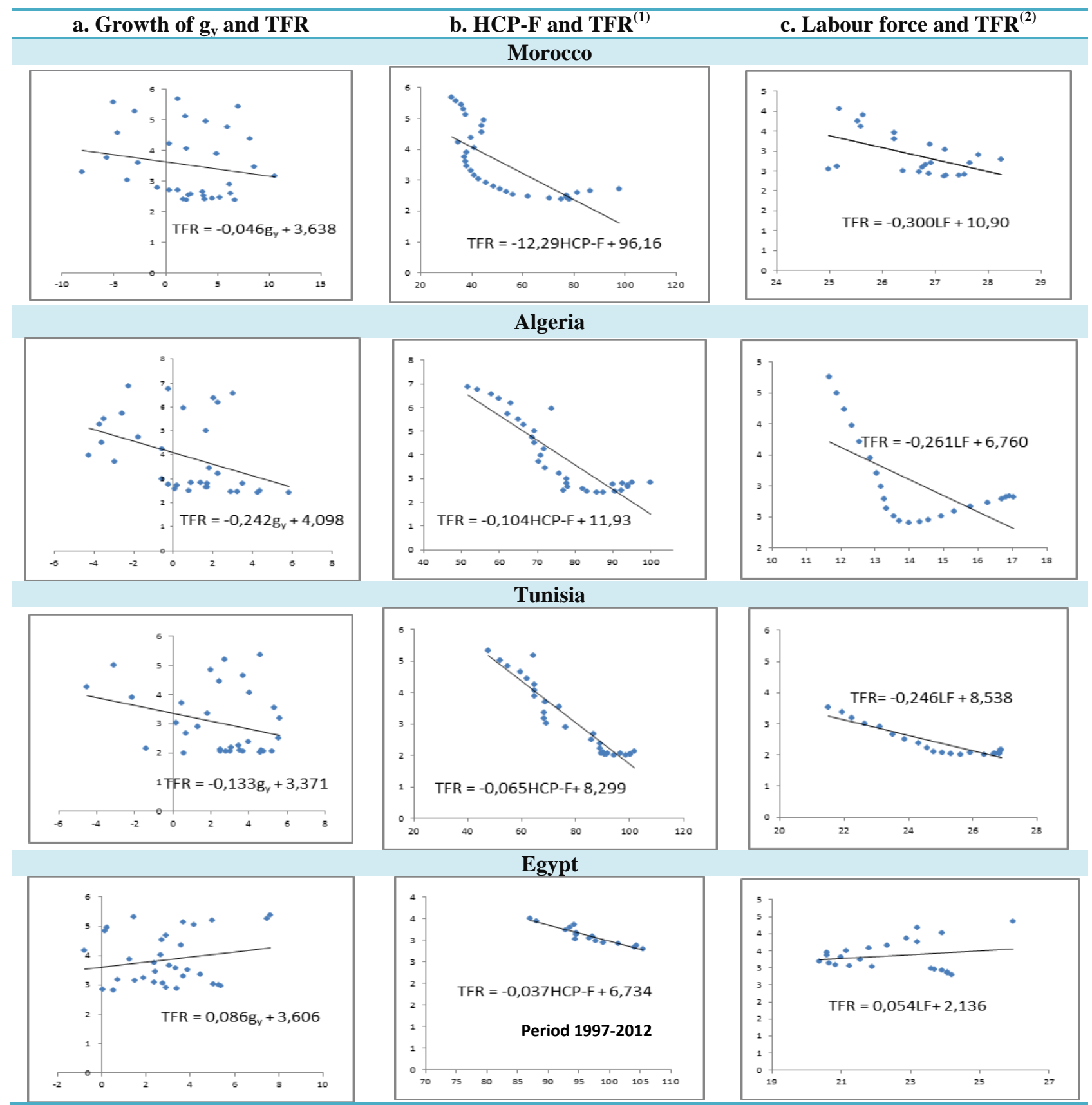

Source: Elaborated using WDI, 2015. (1) Egypt's data is available only over 1997-2012. (2) MATE's data is available only over the period 1990-2012.

Primary completion rate of female (HCP-F) and fertility rate (TFR) are negatively linked, Figure 4(b). The reasoning behind this is quite simple. It states that the fertility rate is driven by female education levels, such as women' education can be accompanied by a corresponding decrease in the fertility rate. Verification of the statistical relationship that links on a simple regression of the fertility rate and other measures of education ('primary school enrolment of female', 'secondary school enrolment of female', and 'tertiary school enrolment of female') reveals similar results. Therefore, there is a negative relationship that links fertility rate and different measures of education.

Excluding Egypt, female participation in labour force (LF) and fertility rate (TFR) are negatively linked, i.e. each $1 \%$ increase in female participation can reduce by between $0.24 \%$ and $0.30 \%$ the fertility rate, Figure 4(c). In addition, growth rate of the real GDP per capita 
$\left(\mathrm{g}_{\mathrm{y}}\right)$ and fertility rate (TFR) are negatively linked, Figure 4(a). If the growth rate of the real GDP per capita increases by $1 \%$, then the rate of fertility decreases by between $0.05 \%$ and $0.24 \%$.

$\Rightarrow$ Second change on MATE is that the literacy rate is on its upward trend from around $55 \%$ in the beginning 1987 to $70 \%$ in 2012. However, an average rate over the period 20062013, literacy rate of the female is always lower than that of male. Table 1 gives an idea about average literacy rates of adult people (ages 15 and above) and of young people (ages 15-24). Measuring in terms of gap between males and females' literacy rates, the differential ranges are just 3 ppt in South Africa and 5 ppt in China, but more than 18 ppt in MATE.

Table 1. Average literacy rate of MATE and of other regions of the World, during 2006-2013 ${ }^{(*)}$

\begin{tabular}{|l|ccc|ccc|}
\cline { 2 - 7 } \multicolumn{1}{c|}{} & \multicolumn{3}{c|}{ People ages 15 and above } & \multicolumn{3}{c|}{ People ages 15-24 } \\
\cline { 2 - 7 } \multicolumn{1}{c|}{} & Female & Male & Total & Female & Male & Total \\
\hline Algeria & 63.9 & 81.3 & 72.6 & 89.1 & 94.4 & 91.8 \\
\hline Egypt & 62.4 & 78.9 & 70.8 & 84.0 & 90.3 & 87.2 \\
\hline Morocco & 48.0 & 71.1 & 59.4 & 72.0 & 87.1 & 79.6 \\
Tunisia & 70.6 & 86.9 & 78.4 & 95.7 & 98.1 & 96.9 \\
\hline South Africa & 91.0 & 93.6 & 92.3 & 98.8 & 98.1 & 98.5 \\
South Asia & 50.4 & 72.8 & 61.4 & 73.3 & 85.7 & 79.3 \\
\hline Sub-Saharan Africa & 51.0 & 68.1 & 59.3 & 64.2 & 75.5 & 69.6 \\
China & 92.7 & 97.5 & 95.1 & 99.6 & 99.7 & 99.6 \\
\hline World & 80.2 & 88.6 & 84.3 & 86.9 & 92.1 & 89.4 \\
\hline
\end{tabular}

Source: calculated using WDI data, 2015. (*) Data is available only over this period for all countries.

$\Rightarrow$ Third remarkable change in MATE is the labour force participation of female in MATE showed that a slight increase from 22\% in 1990 to $24 \%$ in 2012. But, these rates remain lower than that recorded in other regions of the World. Table 2 gives an idea about average labour force participation per gender of adult people (ages 15-64).

Table 2. Average labour force participation per gender (population ages 15-64) in MATE and in other regions of the World, over the period 1990-2009

\begin{tabular}{|l|ccc|ccc|}
\cline { 2 - 7 } \multicolumn{1}{c|}{} & \multicolumn{3}{c|}{ Sub-period 1990-1999 } & \multicolumn{3}{c|}{ Sub-period 2000-2009 } \\
\cline { 2 - 7 } \multicolumn{1}{c|}{} & Female & Male & Total & Female & Male & Total \\
\hline Algeria & 11.8 & 79.8 & 46.1 & 13.8 & 76.5 & 45.5 \\
Egypt & 22.9 & 75.6 & 49.5 & 22.3 & 77.3 & 50.1 \\
Morocco & 29.1 & 83.2 & 55.9 & 28.4 & 81.1 & 54.2 \\
Tunisia & 24.1 & 78.0 & 51.0 & 26.3 & 74.0 & 49.9 \\
EAP (all income levels) & 71.8 & 87.2 & 79.7 & 68.8 & 84.8 & 76.9 \\
\hline LAC (all income levels) & 47.6 & 85.0 & 66.0 & 54.4 & 83.7 & 68.8 \\
MENA (all income levels) & 19.2 & 78.1 & 49.5 & 21.2 & 76.7 & 49.8 \\
OECD members & 57.6 & 81.0 & 69.3 & 59.9 & 79.8 & 69.8 \\
South Africa & 46.7 & 68.8 & 57.6 & 50.7 & 65.5 & 57.9 \\
South Asia & 37.4 & 86.5 & 62.9 & 37.1 & 85.4 & 62.0 \\
Sub-Saharan Africa & 61.4 & 79.4 & 70.3 & 64.0 & 77.0 & 70.5 \\
China & 78.4 & 88.8 & 83.8 & 73.0 & 85.0 & 79.2 \\
\hline World & 57.1 & 84.1 & 70.7 & 56.5 & 82.3 & 69.6 \\
\hline
\end{tabular}

Source: Calculated using WDI data, 2015

Table 2 reveals that the average labour force participation of females is lower than that of males over the period 1990-2009. The highest rate is recorded in China (75\%) and the lowest is recorded in Algeria (13.2\%) over the period 1990-2012. Measuring in terms of the gap between males and females' participation in labour force, differential ranges are just 5 ppt in South Africa and 12 ppt in China, but more than 54 ppt in MATE. 
$\Rightarrow$ Fourth change in MATE is that mortality rates (per 1,000 live births) of neonatal, baby and infant are on their downward trend.

The infant mortality in MATE decreased from an average of 167 per 1,000 live births in 1960 to average of 20 infants per 1,000 live births in 2013, against 34 recorded in the World, Figure 5(a). The neonatal mortality rate decreased also from an average of 29 neonatal per 1,000 live births in 1990 to an average of 13 neonatal per 1,000 live births in 2013, against 20 recorded in the World, Figure 5(b). The baby mortality rate declined, also, from an average of 266 babies per 1,000 live births in 1990 to 23 babies per 1,000 live births in 2016, against 46 recorded in the World, Figure 5(c). All these rates recorded in MATE are lower than that recorded in the World.

Figure No5. Mortality rate per 1,000 live births in MATE and in the World (1960-2013)

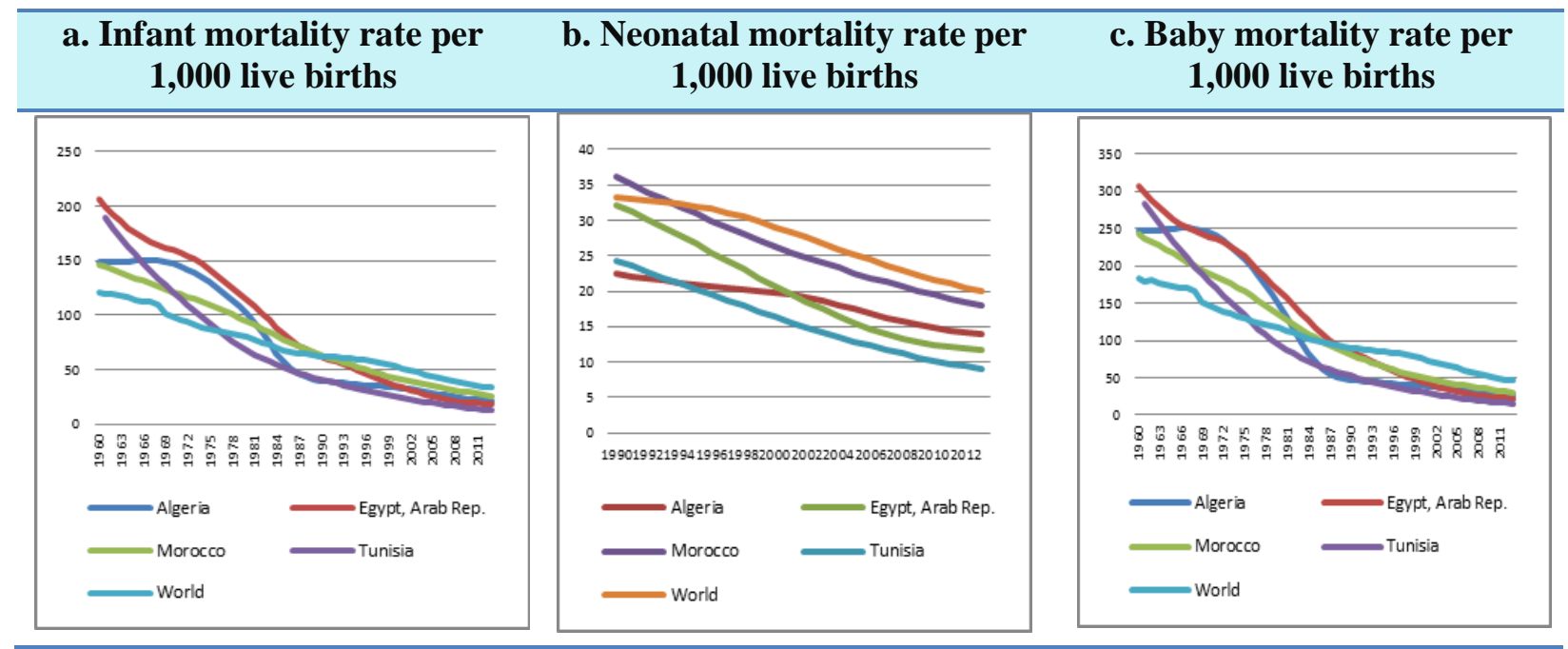

Source: Elaborated using WDI, 2015.

The economic situation for women in MATE records the lowest levels in education and economic activities. There are potentials that have not been used to improve the economic growth of these countries. Several factors continue to affect the access of girls to education and participation in the labour force, such as poverty, gender gap, level of parents' education, infrastructure, religious and cultural norms.

\section{Methodology, data and results}

This study assumes that the human capital is directly proportional to the educational attainment. Since the effects of education on the growth differ by education levels (primary, secondary and higher). Two types of panel models are estimated, a 'general' panel model and a 'gender' panel model. In the first model, education and labour force participation are introduced regardless to gender. The objective is to test if these two variables affect the economic growth. In the second model, each level of education and labour force participation are divided by gender to measure especially if the women' education affects the economic growth.

The 'general' panel model equation is presented as follows.

$$
g_{i t}=\beta_{0}+\beta_{1} p e+\beta_{2} \text { se }+\beta_{3} t e+\beta_{4} l a b o r+\beta_{5} i n{ }_{2} e d u_{i t}+\beta_{6} i c_{i t}+\varepsilon_{i}
$$

Where, the dependent variable is the growth rate of real GDP per capita $\left(\mathrm{g}_{\mathrm{y}}\right)$. The independent variables are total of primary education (pe), total of secondary education (se), total of higher education (te), total of labour participation (labor), investment on education or public expenditure on education (inv_edu) ${ }^{2}$, and institutional capital (ic). Term $\varepsilon$ is the error term.

\footnotetext{
${ }^{2}$ Data of this variable is not available for MATE and of all years.
} 
The 'gender' panel model equation is presented as follows.

$$
\begin{aligned}
& g_{y i t}=\beta_{0}+\beta_{1} \text { pefem }+\beta_{2} \text { pemale }+\beta_{3 \text { sefem }}+\beta_{4 \text { semale }}+\beta_{5 \text { tefem }}+\beta_{6} \text { temale }+ \\
& \beta_{7} \text { laborfem }+\beta_{8} \text { labormale }+\beta_{9 i n v} \text { ed } u_{i t}+\beta_{10 i c} i c_{i t}+\varepsilon_{i}
\end{aligned}
$$

Where, the dependent variable is the growth rate of real GDP per capita $\left(\mathrm{g}_{\mathrm{y}}\right)$. The independent variables are primary education of female (pefem) and of male (pemale), secondary education of female (sefem) and of male (semale), higher education of female (tefem) and of male (temale), labour participation of female (laborfem) and of male (labormale), investment on education or public expenditure on education (inv_edu) and institutional capital (ic). Term $\varepsilon$ is the error term.

This study uses annual data for variables of growth rate of the real GDP, growth rate of the real GDP per capita, primary, secondary and higher school enrolment, and labour force participation in order to analyse the impacts of women' education on the economic growth. All these data are taken from the World Bank. The variables that measured institutional capital are taken from Worldwide Governance Indicators (WGI) (2014). The countries included are Algeria, Morocco, Egypt and Tunisia. The data are balanced panel and involved from 2000 to 2012 because the variables are not available for all countries and all years.

Before applying the classical method to regress equation 1 and equation $\mathbf{2}^{3}$, it is necessary to check the stationarity of the variables. For that, the panel unit root tests are used to check the stationarity of these economic series. Table 3 resumes the results of all tests. However, if these results are not identical we conclude based on most of them.

Table 3. Results of stationarity tests, period 1980-2012

\begin{tabular}{|c|c|c|c|c|c|}
\hline Variables & $\begin{array}{c}\text { Conclusion of all } \\
\text { unit root tests }\end{array}$ & Variables & $\begin{array}{c}\text { Conclusion of all } \\
\text { unit root tests }\end{array}$ & Variables & $\begin{array}{c}\text { Conclusion of all } \\
\text { unit root tests }\end{array}$ \\
\hline $\mathrm{g}$ & $\mathrm{I}(0)$ & pefem & $\mathrm{I}(1)^{*}$ & se & $\mathrm{I}(1)^{*}$ \\
\hline $\mathrm{g}_{\mathrm{y}}$ & $\mathrm{I}(0)$ & pemale & $\mathrm{I}(1)^{*}$ & tefem & $\mathrm{I}(1)^{*}$ \\
\hline laborfem & $\mathrm{I}(1)^{*}$ & pe & $\mathrm{I}(1)^{*}$ & temale & $\mathrm{I}(1)^{*}$ \\
\hline labormale & $\mathrm{I}(1)^{*}$ & sefem & $\mathrm{I}(1)^{*}$ & te & $\mathrm{I}(1)^{*}$ \\
\hline labor & $\mathrm{I}(1)^{*}$ & semale & $\mathrm{I}(1)^{*}$ & \multicolumn{2}{c|}{} \\
\hline
\end{tabular}

Source: Our elaboration. (*) All variables are stationary in the first difference.

Hausman test is used be sure which model would apply the fixed effect model (FE) or the random effect model (RE). Table 4 displays the result of the 'general' panel model (equation 1) which mentioned that there are three main results. The first result is that the tertiary school enrolment (te) is positively and significantly linked to the economic growth (measured by $\mathrm{g}$ and $g_{y}$ ). The second result is that the variables of institutional capital (icr, icg, icva and icl) are positively linked to the economic growth. The third result is, surprisingly, that the primary and secondary school enrolments are negatively linked to the economic growth.

\footnotetext{
${ }^{3}$ We also run these two equations with the real GDP as endogenous variable.
} 
Table 4. Results of the 'general' panel model (fixed effect model), sample: 2000-2012

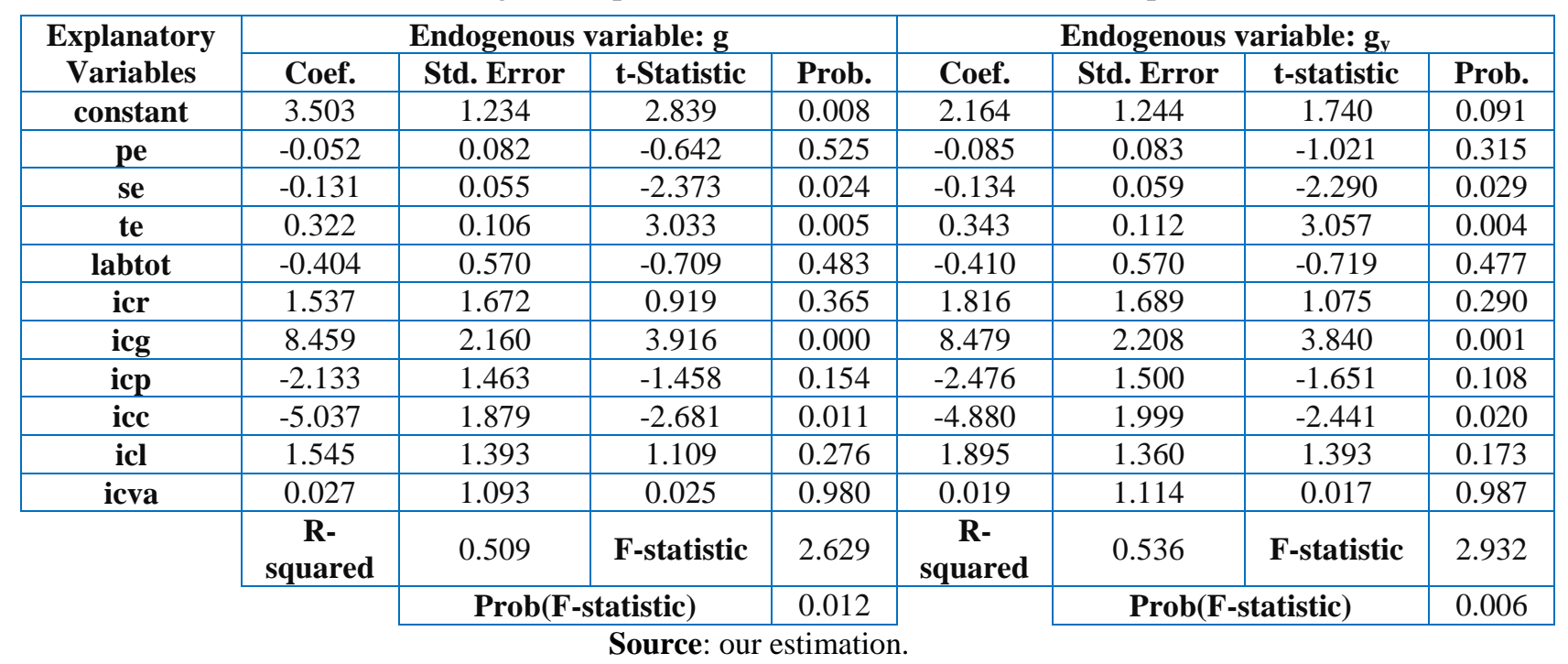

The results of 'gender' panel model (equation 2) are given in Table 5. There are five main results. The first result is that the primary school enrolment of males is positively and significantly linked to the economic growth, but that of females is negatively and significantly at $10 \%$ linked to the economic growth. The second result is that the secondary school enrolment of males and females are negatively linked, albeit insignificantly, to the economic growth as like in the 'general' panel model. The third result is that the tertiary school enrolment of males and females are positively linked to the economic growth. The fourth result is that the institutional capital (icg, icr, and icva) is positively linked to the economic growth and it is like in the 'general' panel model. The fifth result is that the labour force participation of females is positively linked to the economic growth. In contrast, the labour force participation of males is negatively linked to the economic growth.

Table 5. The results of ' gender' panel model (equation 2), (fixed effect model), sample: 2000-2012

\begin{tabular}{|c|c|c|c|c|c|c|c|c|}
\hline \multirow{2}{*}{$\begin{array}{c}\text { Explanatory } \\
\text { Variables }\end{array}$} & \multicolumn{4}{|c|}{ Endogenous variable: $g$} & \multicolumn{4}{|c|}{ Endogenous variable: $g_{y}$} \\
\hline & Coef. & Std. Error & t-Statistic & Prob. & Coef. & Std. Error & t-statistic & Prob. \\
\hline Constant & 3.729 & 1.242 & 3.002 & 0.006 & 2.411 & 1.283 & 1.879 & 0.072 \\
\hline pefem & -0.204 & 0.108 & -1.895 & 0.070 & -0.189 & 0.109 & -1.733 & 0.096 \\
\hline pemale & 0.384 & 0.131 & 2.943 & 0.007 & 0.325 & 0.135 & 2.415 & 0.023 \\
\hline sefem & -0.093 & 0.087 & -1.058 & 0.300 & -0.066 & 0.095 & -0.688 & 0.498 \\
\hline semale & -0.049 & 0.103 & -0.480 & 0.635 & -0.073 & 0.108 & -0.678 & 0.504 \\
\hline tefem & 0.100 & 0.150 & 0.667 & 0.511 & 0.125 & 0.154 & 0.809 & 0.426 \\
\hline temale & 0.056 & 0.083 & 0.679 & 0.504 & 0.051 & 0.087 & 0.586 & 0.563 \\
\hline labfem & 0.123 & 0.335 & 0.366 & 0.717 & 0.132 & 0.334 & 0.394 & 0.697 \\
\hline labmale & -0.602 & 0.136 & -4.422 & 0.000 & -0.570 & 0.147 & -3.873 & 0.001 \\
\hline icl & -0.552 & 1.507 & -0.366 & 0.717 & -0.480 & 1.577 & -0.304 & 0.764 \\
\hline icr & 1.133 & 1.345 & 0.842 & 0.408 & 1.238 & 1.374 & 0.901 & 0.376 \\
\hline icc & -5.850 & 1.456 & -4.019 & 0.001 & -5.743 & 1.520 & -3.779 & 0.001 \\
\hline icg & 8.203 & 1.929 & 4.252 & 0.000 & 7.782 & 1.938 & 4.015 & 0.001 \\
\hline icva & 0.215 & 1.106 & 0.194 & 0.847 & 0.207 & 1.148 & 0.180 & 0.858 \\
\hline \multirow[t]{3}{*}{ icp } & -0.266 & 1.278 & -0.208 & 0.837 & -0.192 & 1.322 & -0.145 & 0.886 \\
\hline & R-squared & 0.639 & F-Statistic & 2.602 & R-squared & 0.653 & F-Statistic & 2.762 \\
\hline & & \multicolumn{2}{|c|}{ Prob(F-statistic) } & 0.015 & & \multicolumn{2}{|c|}{ Prob(F-statistic) } & 0.010 \\
\hline
\end{tabular}

Source: Our estimation. 


\section{Conclusion}

After discussing results of the panel models, it is necessary to recognize that MATE countries differ significantly from one to another in the characteristics that influence how women' education may affect the economic growth. The differing political and economic histories and geographical circumstances of these countries have created an array of environments in which women' education institutions operate.

Our results show positive impacts of women' education on the economic growth especially tertiary education. Other important result is that the variables of institutional capital play an important role on the economic growth. So, to attain sustainable, rapid and continuous economic growth, it is necessary to encourage especially tertiary education of woman through establishing economic and social strategy able to improve women' situation and, in addition, reducing poverty of the citizens.

\section{References}

[1] Barro, R. J., (1996). "Determinants of Economic Growth: A Cross-Country Empirical Study," NBER Working Papers 5698.

[2] Barro, R. J., (2013). "Education and Economic Growth," Annals of Economics and Finance, Society for AEF, vol. 14(2), pp. 301-328.

[3] Becker, G.S., (1962), "Investment in Human Capital: A Theoretical Analysis". Journal of Political Economy, 70(5): pp.9-19.

[4] Blaug, M., (1976). "The Empirical Status of Human Capital Theory: A Slightly Jaundiced Survey". Journal of Economic Literature, 14(3): 827-55.

[5] Bloom, D. Canning, D. and Chan, K., (2006), "Higher Education and Economic Development in Africa", Human Development Sector Africa Region. http://ent.arp. harvard.edu/ AfricaHigherEducation/Reports/BloomAndCanning.pdf

[6] Hill M. A., and King E., (1995). "Women' education and economic well-being". Feminist Economics, vol. 1, issue 2, pages 21-46

[7] Klasen, S. (2002), "Low schooling for girls, slower growth for all? Cross-country evidence on the effect of gender inequality in education on economic development", The World Bank Economic Review, vol.16, no.3, pp. 345-373.

[8] Mincer, J., (1958), "Investment in human capital and personal income distribution", Journal of Political Economy, 66(4): 281-302.

[9] Mincer, J., (1962), "On-the-job training: Costs, returns, and some implications", Journal of Political Economy, 70: 50-79.

[10] Organization of Islamic Cooperation, (2011), "Human capital accumulation in OIC member countries", OIC Outlook series No: 29, April 2011.

[11] Psacharopoulos, G., (1994). "Returns to Investment in Education: A Global Update", World Development, Vol. 22, No 9, pp. 132.5-1 343.

[12] Schultz, T.W., (1961), "Investment in human capital", The American Economic Review, 51(1): $1-17$.

[13] Schultz, T.W., (1962), "Reflexions on investment in man", Journal of Political Economy, 70(5): $1-8$.

[14] UN-Women (2013), "Regional Consultation for the Proposed General Recommendation on Women Human Rights in Situations of Conflict and Post Conflict contexts", AMMAN, January 2013, UN WOMEN For Arab States \& The Committee on Elimination of Discrimination Against Women (CEDAW Committee). 